\title{
A Question of Flexibility in Cytochrome c Oxidase Models
}

Pauline Vorburger, ${ }^{\mathrm{a}}$ Mamadou Lo, ${ }^{\mathrm{a}}$ Sylvie Choua, ${ }^{\mathrm{a}}$ Maxime Bernard, ${ }^{\mathrm{a}}$ Frédéric Melin, ${ }^{\mathrm{b}}$ Nesrine Oueslati, ${ }^{\mathrm{b}}$ Corinne Boudon, ${ }^{\mathrm{a}}$ Mourad Elhabiri, ${ }^{\mathrm{c}}$ Jennifer A. Wytko, ${ }^{\text {a }}$ Petra Hellwig ${ }^{\mathrm{b}}$ and Jean Weiss ${ }^{* a}$

a) Institut de Chimie, UMR 7177 CNRS-Université de Strasbourg, Institut de Chimie de Strasbourg, 4, rue Blaise Pascal 67008 Strasbourg, France, b) Laboratoire de Biochimie et Spectroscopie, UMR 7140-CNRS-Université de Strasbourg, Institut de Chimie de Strasbourg, 4, rue Blaise Pascal, 67008 Strasbourg, France, c) Laboratoire de Chimie Bioorganique et Médicinale, UMR 7509 CNRS-Université de Strasbourg, ECPM, 25 Rue Becquerel, 67087 Strasbourg Cedex, France.

CORRESPONDING AUTHOR: e-mail: jweiss@unistra.fr

\begin{abstract}
The structure-property relationships were compared for the iron and iron-copper complexes of two functional cytochrome c oxidase models, $\mathbf{1}$ and $\mathbf{2}$, both constructed upon a phenanthroline-strapped porphyrin bearing respectively pyridyl or picolinyl built-in proximal and distal ligands. The behavior of these heme models in the absence and in the presence of copper was studied by ${ }^{1} \mathrm{H}$ NMR, UV-visible absorption, EPR, Raman and FTIR spectroscopies, electrochemistry in solution and deposited on a rotating ring-disk graphite electrode. The distal binding site within the phenanthroline pocket of both $\mathbf{1}$ and $\mathbf{2}$ is available for the coordination of exogenic ligands, yet the oxygen binding affinity is higher for all complexes of $\mathbf{2}$ than for $\mathbf{1}$. Despite this difference, $\left[\mathbf{1 F e}^{\mathrm{II}} \mathbf{C u}^{\mathrm{I}}\right]$ more efficiently reproduced the electrocatalyzed reduction of
\end{abstract}


oxygen to water than $\left[\mathbf{2} \mathbf{F e}^{\mathrm{II}} \mathbf{C u}^{\mathrm{I}}\right]$. The oxygenated complexes of both iron(II)-copper(I) species mimic the ability of cytochrome c oxidase to reversibly bind $\mathrm{O}_{2}$, as shown by competitive binding studies in the presence of CO. Differences in the binding and electrocatalytic properties of these models stem from difference in rigidity of scaffolds upon binding of both the proximal and distal ligands, as well as from the bulkiness of the distal ligand.

KEYWORDS Cytochrome $c$ oxidase, heme protein models, porphyrin, phenanthroline, oxygen binding, carbon monoxide binding.

\section{Introduction}

Cytochrome $c$ oxidase $(\mathrm{CcO})$ is the terminal enzyme in the anaerobic respiration of mitochondria and aerobic bacteria and performs the four-electron reduction of oxygen into water. This redox process is fueled by four cytochrome $c$ cycles and coupled to ATP synthesis [1]. The active site for oxygen binding comprises a ferrous heme (heme $\mathrm{a}_{3}$ ) and a cuprous copper center $\left(\mathrm{Cu}_{\mathrm{B}}\right)$ separated by $\sim 5 \mathrm{~A}$ in the fully reduced active site of the enzyme [2,3]. Several functional and structural mimics have been studied to establish the respective roles of iron, copper and the influence of amino acids such as tyrosine located in the vicinity of the proximal site, mostly by comparing the functional behavior of the models with that of the enzyme $[4,5,6,7,8]$. In general, the function of hemoproteins is fine tuned by the distal residue that controls the approach, position and polarization of exogenic axial ligands. Several groups have successfully reproduced such a controlled environment by using porphyrin derivatives that bear caps or straps, which mimic amino acid functions $[4,7,9]$.

In the particular case of functional models of $\mathrm{CcO}$, special attention has been devoted to ligands able to bind copper in both +1 and +2 oxidation states. Depending on the history of each 
research group in this field, imidazoles, $N$-alkylimidazoles or pyridines were utilized as pendant ligands for copper(II/I) and were linked to the porphyrin architecture via various connectors. $[8,10,11]$ As a result of these numerous variations, a rational comparison of each model's behavior is still very difficult. Over the years, our group has used a phenanthroline-strapped porphyrin [12] as a multi-purpose starting material to explore fields ranging from enzyme mimics to self-assembled porphyrin wires [13]. Because of the unique features of the phenanthrolinestrapped architecture, it has been possible to compare $\mathrm{C} c \mathrm{O}$ models in which the copper binding site is almost constant [14]. The work described hereafter shows how small architectural variations of the organic scaffolding affect both the exogenic ligand binding and the reactivity of the iron center.

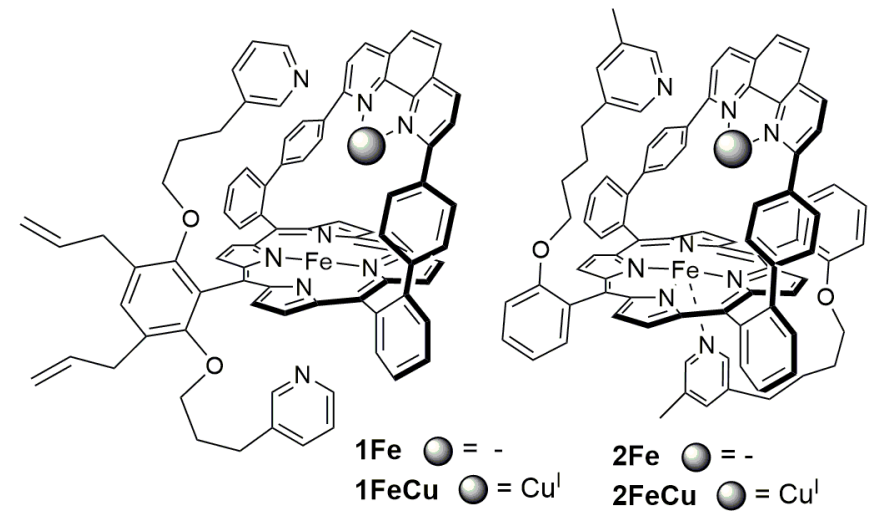

Figure 1. Cytochrome c oxidase models built around a phenanthroline-strapped porphyrin. The phenanthroline pocket provides the distal binding site, whereas the open face of the porphyrin is the proximal site.

In the presence of molecular dioxygen, the previously reported ditopic ligand 1 [15] (Figure 1) provided a realistic mimic of the first oxygenated intermediate in the catalytic cycle of $\mathrm{CcO}$ [16]. However, although the iron-copper complex $\left[1 \mathrm{Fe}^{\mathrm{II}} \mathrm{Cu}^{\mathrm{I}}\right]^{+}$catalyzed the reduction of oxygen to water by a predominant four-electron mechanism, our attention was caught by the apparent lability of the proximal pyridyl ligand that was observed during titration experiments with various imidazoles (vide infra) and assigned to tension in the pendant ligands. To reduce this 
constraint, model 2 (Figure 1) [17] was designed such that the proximal and distal ligands moved independently of one another. In addition, the alkyl chains, from the meso-phenyl rings to the picoline ligands, were lengthened by one methylene unit to provide a fully flexible scaffolding. A major drawback of compound 1 was the coordination of the distal pyridine to iron(II) within the phenanthroline pocket, giving a hexacoordinated iron(II) that was relatively inert towards oxygen binding. Replacing the pyridines with a bulkier picoline in $\mathbf{2}$ would hopefully favor the formation of a pentacoordinated iron(II) complex and in turn vacate the distal site for oxygen binding within the phenanthroline pocket. Hereafter, the coordination geometries, as well as the binding properties at the distal site of iron and iron-copper complexes of models $\mathbf{1}$ and $\mathbf{2}$ towards a series of exogenic ligands, including imidazoles, oxygen and carbon monoxide, are compared by NMR, EPR, IR spectroscopies and electrochemistry.

\section{Results and Discussion}

\section{Fe $\mathrm{III}^{\mathrm{III}}$ complexes}

The iron(III) complex $\left[\mathbf{2 F e} e^{\mathrm{III}}\right] \mathbf{C l}$ and the previously reported $\left[\mathbf{1 F e} \mathbf{e}^{\mathrm{III}}\right] \mathbf{C l}[15]$ were prepared quantitatively, according to a modified literature procedure [18], by treatment of the corresponding free base ligands with $\mathrm{FeCl}_{2}$, followed by oxidation with air. The pentacoordination of both iron(III) complexes, $\left[\mathbf{1 F e} e^{\mathrm{III}}\right]^{+}$and $\left[\mathbf{2} \mathbf{F e}^{\mathrm{III}}\right]^{+}$, was confirmed by ${ }^{1} \mathrm{H}$ NMR, EPR and UV-visible absorption spectroscopies. ${ }^{1} \mathrm{H}$ NMR spectra clearly showed paramagnetic high spin iron(III) complexes with the $\beta$-pyrrolic protons near $80 \mathrm{ppm}$. The paramagnetic, high spin pentacoordinated nature of both complexes was confirmed by characteristic effective $g$ values (5.86-5.89) and (2.05-2.06) values in the EPR spectra of frozen samples. Finally, the Soret region of electronic spectrum displayed absorptions typical of iron(III) complexes, with an absorption at $424 \mathrm{~nm}$ for $\left[\mathbf{1 F e} \mathbf{e}^{\mathrm{III}}\right]^{+}[15]$ and $428 \mathrm{~nm}$ for $\left[\mathbf{2} \mathbf{F e}^{\mathrm{III}}\right]^{+}$. 
The availability of the distal coordination site on the central $\mathrm{Fe}^{\mathrm{III}}$ core was studied by both UV-visible absorption spectroscopy and EPR by adding imidazole derivatives to $\left[\mathbf{1 F e}{ }^{\mathrm{III}}\right]^{+}$and $\left[2 \mathrm{Fe}^{\mathrm{III}}\right]^{+}$. Large changes of the electronic spectra upon the addition of imidazole, 2methylimidazole or $\mathrm{N}$-methylimidazole to solutions of each iron(III) complex in $\mathrm{CH}_{2} \mathrm{Cl}_{2}$ at $298 \mathrm{~K}$ (see supporting information) suggested the formation of hexacoordinated iron(III) species. Job plots for $\left[\mathbf{1 F e} \mathbf{I I I}^{+}\right.$with each imidazole clearly confirmed the hexacoordinated geometry, with two imidazoles per iron porphyrin. For $\left[\mathbf{2} \mathbf{F e}^{\mathrm{III}}\right]^{+}$, absorption spectral changes were minimal after the addition of 1 equivalent of each imidazole derivative. Even in the presence of a large excess of the imidazole guest, there was no evidence for the formation of $1: 2\left[\mathbf{2 F} \mathbf{e}^{\mathrm{III}}\right]^{+}$:imidazole complexes. The coordination of imidazole or 2-methylimidazole within the distal pocket of both $\left[\mathbf{1 F e} \mathbf{e}^{\mathrm{III}}\right]^{+}$and $\left[\mathbf{2} \mathrm{Fe}^{\mathrm{III}}\right]^{+}$was further demonstrated by modifications of the phenanthroline's absorption band near 280-290 $\mathrm{nm}$ due to the formation of hydrogen bonds between the imidazole $\mathrm{NH}$ and the nitrogen atoms of the phenanthroline [16]. No such spectral variation was observed during the titration of $\left[\mathbf{1 F e} e^{\mathrm{III}}\right]^{+}$with $N$-methylimidazole, for which hydrogen bonding within the phenanthroline pocket is unlikely.

Table 1. Binding constants for $1 / 1$ and $1 / 2$ ligand/substrate $(\mathrm{L} / \mathrm{S})$ complexes determined from UV-visible absorption titrations of $\left[1 \mathbf{F e}^{\mathrm{III}}\right]^{+}$or $\left[\mathbf{2} \mathrm{Fe}^{\mathrm{III}}\right]^{+}$with imidazole derivatives in $\mathrm{CH}_{2} \mathrm{Cl}_{2}$ at $298 \mathrm{~K}$.

Successive association $\log \mathbf{K}$

\begin{tabular}{|c|c|c|c|c|c|c|}
\hline & \multicolumn{2}{|c|}{ imidazole } & \multicolumn{2}{|c|}{$N$-methylimidazole } & \multicolumn{2}{|c|}{ 2-methylimidazole } \\
\hline & $\mathrm{L}: \mathrm{S}$ & $\mathrm{L}: \mathrm{S}_{2}$ & $\mathrm{~L}: \mathrm{S}$ & $\mathrm{L}: \mathrm{S}_{2}$ & $\mathrm{~L}: \mathrm{S}$ & $\mathrm{L}: \mathrm{S}_{2}$ \\
\hline$\left[1 \mathrm{Fe}^{\mathrm{III}}\right]^{+}$ & (a) & $\log \beta=11.9 \pm 0.6$ & $4.2 \pm 0.6$ & $\begin{array}{l}3.6 \pm 0.8 \\
\log \beta=7.8 \pm 0.7\end{array}$ & $6.9 \pm 0.3$ & $\begin{array}{l}6.5 \pm 0.6 \\
\log \beta=13.4 \pm 0.5\end{array}$ \\
\hline$\left[2 \mathrm{Fe}^{\mathrm{III}}\right]^{+}$ & $5.40 \pm 0.07$ & (b) & $5.63 \pm 0.09$ & (b) & $6.2 \pm 0.1$ & (b) \\
\hline
\end{tabular}

The errors are given as $3 \sigma$ with $\sigma=$ standard deviation. (a) Not determined. (b) Not observed. 
The binding constants of $\left[\mathbf{1 F e} e^{\mathrm{III}}\right]^{+}$and $\left[\mathbf{2} \mathbf{F e}^{\mathrm{III}}\right]^{+}$with imidazole guests (Table 1) were then calculated by statistical processing of the titration data sets. Porphyrin $\left[\mathbf{2} \mathbf{F e}^{\mathrm{III}}\right]^{+}$forms only $1: 1$ complexes with all three imidazoles, indicating that one of the two pendant picoline arms remains tightly bound to the iron(III) center and is not exchanged by the competing imidazole substrates. For $\left[\mathbf{1 F e} e^{I I I}\right]^{+}$, the competing formation of both 1:1 and 1:2 ligand:substrate complexes was systematically observed. The formation of 1:2 complexes is attributed to a relatively labile coordination of the built-in pyridyl ligand due to strain within the pentacoordinated iron scaffold of the 1:1 complex. Only the binding constant of a 1:2 complex of $\left[\mathbf{1 F e} \mathbf{e}^{\mathrm{III}}\right]^{+}$with imidazole could be determined, possibly because the first equivalent of imidazole binds indifferently at the distal or proximal site. At both sites, binding is stabilized by the formation of a hydrogen bond of the imidazole's NH with the nitrogen atoms of either the phenanthroline in the distal pocket or the built-in proximal pyridine.

Evolution of the EPR spectra upon addition of various imidazoles to $\left[\mathbf{1 F e} \mathbf{e}^{\mathrm{III}}\right]^{+}$and $\left[\mathbf{2} \mathrm{Fe}^{\mathrm{III}}\right]^{+}$are provided as supporting information. Addition of one equivalent of nitrogen base led to the formation of the hexacoordinated ferric species with the superimposed high-spin pentacoordinated species for [1Fe $\left.\mathbf{1 F I}^{\mathrm{II}}\right]^{+}$(see supporting information). The "large- $g_{\max }$ " feature [19] observed at $g=3.21$ and $g=2.24$ and the peak at $g=4.29$ suggest a mixture of $S=3 / 2$ and $5 / 2$ spin states, respectively. As the number of equivalents of ligand increased, the intensity of the fourth peak at $g=5.89$ decreased; the decrease was more pronounced for the imidazole and 2methylimidazole ligands. The high spin signal disappeared completely after the addition of only three equivalents of imidazole and 2-methylimidazole. In contrast, addition of 10 equivalents of $N$-methylimidazole merely reduced the peak's intensity by roughly half (see supporting information). This difference suggests a better stabilization of the imidazole-iron complex by hydrogen bonding between the $\mathrm{NH}$ proton of imidazole or 2-methylimidazole and the two 
nitrogen atoms of the phenanthroline binding site. In contrast, the binding of $N$-methylimidazole is less favorable due to the absence of an NH proton. This result satisfactorily follows the same trend as the association constants obtained from UV-visible absorption titrations.

In contrast, for $\left[\mathbf{2 F} \mathbf{e}^{\mathrm{III}}\right]^{+}$the intensity of the EPR signal assigned to high spin pentacoordinated species decreased significantly upon addition of only one equivalent of the various imidazoles (see supporting information). This result highlights the role of the picoline's methyl substituent that prevents binding of the distal picoline to the iron(III), thus facilitating the coordination of the nitrogen ligand. The more basic character of the proximal picoline ligand also precludes its displacement by the competing imidazole, which is consistent with the UV-visible titration observations. Overall, the EPR and UV-visible absorption binding studies with both iron(III) complexes were particularly useful to confirm the availability of the distal binding site for small exogenic ligands. Oxygen binding was subsequently investigated with the iron(II) derivatives.

\section{Fe $\mathrm{e}^{\mathrm{II}}$ complexes}

The pentacoordinated, high spin $(\mathrm{S}=5 / 2)$ iron(III) complexes were reduced to their corresponding iron(II) complexes by treatment with sodium dithionite. The ${ }^{1} \mathrm{H}$ NMR spectrum (see supporting information) of [1Fe $\left.\mathbf{1}^{\mathrm{II}}\right]$ was typical of a diamagnetic, low spin $(\mathrm{S}=0)$ species and suggested a hexacoordinated iron(II) in which both the proximal and distal pendant pyridines were coordinated to the central ferrous center (see supporting information). In contrast, for $\left[\mathbf{2 F} \mathbf{e}^{\mathrm{II}}\right]$, the broad ${ }^{1} \mathrm{H}$ NMR spectra displayed a signal for the $\beta$-pyrrolic protons at 40 ppm that is characteristic of a high spin, pentacoordinated iron(II) center (see supporting information). Binding of the distal picoline to the iron(II) must therefore be hindered by the picoline's methyl substituent that does not fit within the phenanthroline strap. 
The hexacoordinated low spin $(\mathrm{S}=0)\left[\mathbf{1 F e}^{\mathrm{II}}\right]$ complex was relatively inert to air exposure but persistent oxygen bubbling into the solution yielded a new diamagnetic species. The broad signals in the ${ }^{1} \mathrm{H}$ NMR spectrum of the oxygenated species suggested that the oxygenated $(\mathrm{S}=0)$ form was in slow equilibrium with the original hexacoordinated [1Fe $\left.{ }^{\mathrm{II}}\right]$ complex bearing the two pyridines as axial bases (see supporting information). Coordination of carbon monoxide on [1Fe $\left.{ }^{\mathrm{II}}\right]$ was thus used to identify the preferred coordination site (distal or proximal) for a small exogenic ligand. Upon exposure to CO, two peaks, assigned to the coordinated distal pyridine of the original $\left[\mathbf{1 F e}^{\mathrm{II}}\right]$ complex, disappeared and thus confirmed the replacement of this distal ligand by the exogenic $\mathrm{CO}$ (supporting information).

In contrast to $\left[\mathbf{1 F e}^{\mathrm{II}}\right]$, porphyrin $\left[\mathbf{2} \mathbf{F e}^{\mathbf{I I}}\right]$ was very sensitive to even trace amounts of oxygen, making it difficult to observe absorption spectrum of the oxygen-free iron(II) complex [2Fe $\left.\mathbf{e}^{\mathrm{II}}\right]$. This observation qualitatively suggests that $\left[\mathbf{2} \mathbf{F e}^{\mathrm{II}}\right]$ has a higher affinity than $\left[\mathbf{1 F} \mathbf{e}^{\mathrm{II}}\right]$ for oxygen binding. Upon bubbling of oxygen into a $\mathrm{CHCl}_{3}$ solution of $\left[\mathbf{2} \mathbf{F e}^{\mathrm{II}}\right]$, the signals of the ${ }^{1} \mathrm{H} \mathrm{NMR}$ spectrum (Figure 2) were relatively well resolved and appeared between 0-15 ppm, indicating a diamagnetic [2Fe $\left.\mathbf{F e}^{\mathrm{II}}\left(\mathbf{O}_{2}\right)\right]$ complex. To demonstrate the reversible binding of oxygen, CO was bubbled into the solution of $\left[\mathbf{2 F} \mathbf{e}^{\mathrm{II}}\left(\mathbf{O}_{2}\right)\right]$, causing a rapid color change from red to green. 


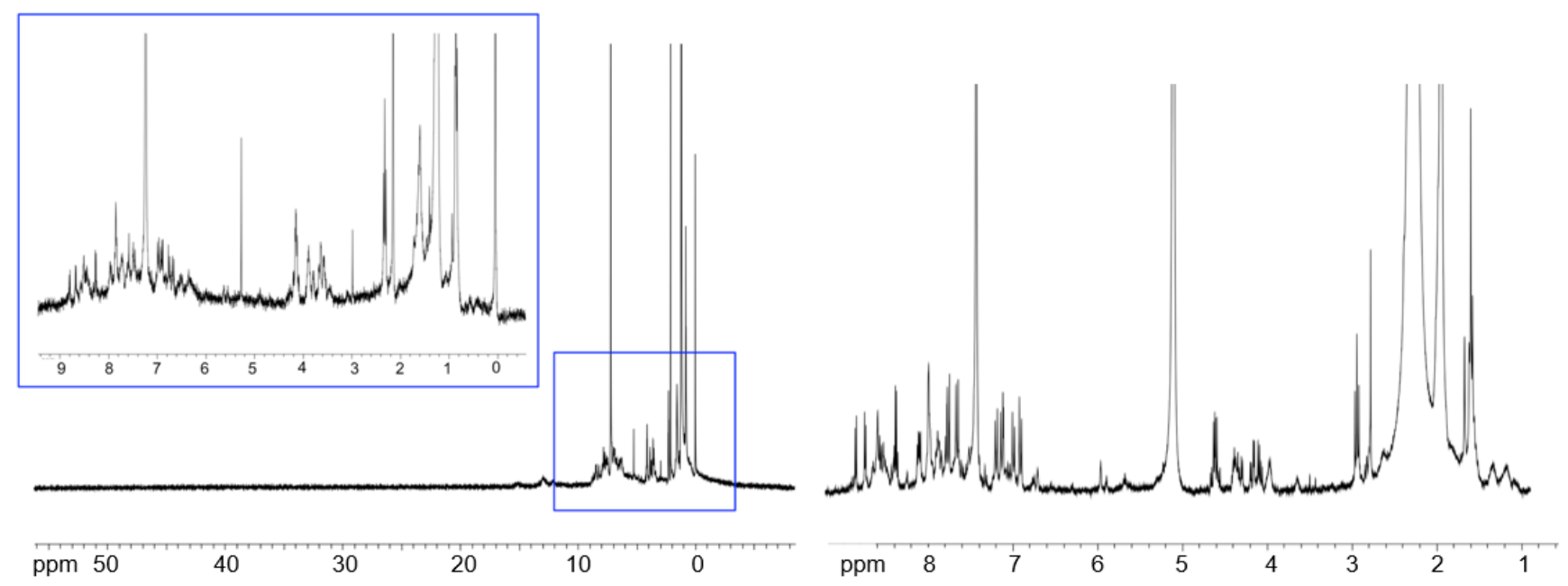

Figure 2. ${ }^{1} \mathrm{H}$ NMR spectra $\left(300 \mathrm{MHz}, \mathrm{CDCl}_{3}\right)$ of $\left[2 \mathrm{Fe}^{\mathrm{II}}\right]$ in the presence of $\mathrm{O}_{2}$ (left) and $\mathrm{CO}$ (right).

In the presence of $\mathrm{CO}$, the NMR spectrum remains relatively sharp, although the peaks could not be attributed (Figure 2). In the electronic spectrum, the intensity of the Soret band increased and was blue-shifted by $4 \mathrm{~nm}$ compared to the Soret band of [2Fe $\left.{ }^{\mathrm{II}} \mathbf{O}_{2}\right]$ (supporting information). Both features are characteristic of a hexacoordinated iron(II) with $\mathrm{CO}$ bound as an exogenic ligand.

To summarize the reactivity of the two iron(II) complexes towards oxygen, porphyrin [2Fe $\left.{ }^{\mathrm{II}}\right]$ more readily binds oxygen than $\left[\mathbf{1 F e}^{\mathrm{II}}\right]$ due to the different type of built-in distal ligand present in each complex. In $\left[2 \mathbf{F e}^{\mathrm{II}}\right]$, the methyl substituent of the picoline inhibits coordination of the distal picoline within the phenanthroline pocket and favors a pentacoordinated iron(II) complex with an available distal binding site. The less bulky pyridyl ligand of $\left[\mathbf{1 F} \mathbf{e}^{\mathrm{II}}\right]$, on the other hand, fits in the distal pocket and binds at the distal site of the iron(II) to afford a hexacoordinated species. Thus, for oxygen to bind at the distal site, decoordination of the pyridine must first occur. 


\section{$\mathrm{Fe}^{\mathrm{III}}-\mathrm{Cu}^{\mathrm{I}}$ and $\mathrm{Fe}^{\mathrm{II}}-\mathrm{Cu}^{\mathrm{I}}$ complexes}

The previous experiments indicate that whereas the distal pyridine of $[\mathbf{1 F e}]$ is not coordinated in the ferric state, it is bound to the central Fe core in the ferrous state, which induces a slow and incomplete binding of molecular dioxygen to $\left[\mathbf{1 F e}^{\mathrm{II}}\right]$. One possibility to prevent this unwanted coordination feature in $\left[\mathbf{1 F e}{ }^{\mathrm{II}}\right]$ is to divert the distal pyridine to the coordination sphere of a copper atom located within the phenanthroline binding site, thus completing an entire $\mathrm{CcO}$ model. The heterobimetallic iron-copper complexes of both $\mathbf{1}$ and $\mathbf{2}$ were synthesized by addition of one equivalent of $\left[\mathrm{Cu}\left(\mathrm{CH}_{3} \mathrm{CN}\right)_{4}\right] \mathrm{PF}_{6}$ to $\left[1 \mathrm{Fe}^{\mathrm{III}}\right]^{+}$or $\left[2 \mathrm{Fe}^{\mathrm{III}}\right]^{+}$. The coordination of copper(I) was monitored by UV-visible absorption spectrophotometry, especially in the UV region where modifications of the phenanthroline's absorption bands were clearly seen upon coordination of copper(I) (supporting information). Reduction of the pentacoordinated ferric complexes $\left[1 \mathrm{Fe}^{\mathrm{III}} \mathrm{Cu}^{\mathrm{I}}\right]^{2+}$ or $\left[2 \mathrm{Fe}^{\mathrm{III}} \mathrm{Cu}^{\mathrm{I}}\right]^{2+}$ in biphasic medium with aqueous sodium dithionite immediately produced the sharp red-shifted Soret band of the ferrous analogues $\left[\mathbf{1 F} \mathbf{e}^{\mathrm{II}} \mathbf{C u}^{\mathrm{I}}\right]^{+}$and $\left[2 \mathrm{Fe}^{\mathrm{II}} \mathrm{Cu}^{\mathrm{I}}\right]^{+}$.

The formation of these complexes was also monitored by ${ }^{1} \mathrm{H}$ NMR. The initial spectrum of $\left[1 \mathrm{Fe}^{\mathrm{II}} \mathrm{Cu}^{\mathrm{I}}\right]^{+}$is typical of a high spin $(\mathrm{S}=2)$ pentacoordinated $\mathrm{Fe}^{\mathrm{II}}$ complex, with the $\beta$-pyrrolic protons appearing in the range of 40 to $50 \mathrm{ppm}$ and the spectrum spread over $70 \mathrm{ppm}$ (Figure 3). Although it is difficult to interpret the modifications induced by the introduction of $\mathrm{Cu}^{\mathrm{I}}$ due to the lack of a reference spectrum, the paramagnetic behavior of the reduced complex $\left.\left[1 \mathbf{F e}^{\mathrm{II}} \mathbf{C u}\right]^{\mathrm{I}}\right]^{+}$was strikingly different from that of the diamagnetic ferrous complex $\left[\mathbf{1 F e} \mathbf{e}^{\mathrm{II}}\right]$ obtained in the absence of $\mathrm{Cu}^{\mathrm{I}}$. Clearly, the presence of the copper in the phenanthroline binding site prevents the distal pyridine from approaching the $\mathrm{Fe}^{\mathrm{II}}$ core and thus preserves the high spin $(\mathrm{S}=2)$ state of the heme model. In $\left[\mathbf{1 F e} e^{\mathrm{II}} \mathbf{C u}^{\mathrm{I}}\right]^{+}$, the distal pyridyl ligand is probably coordinated to the copper(I). 
a) $\mathrm{Fe}^{\mathrm{III}}-\mathrm{Cu}^{\prime} \longrightarrow \mathrm{Fe}^{\mathrm{ll}}-\mathrm{Cu}$ $\mathrm{S}=2$ pentacoordinated high spin

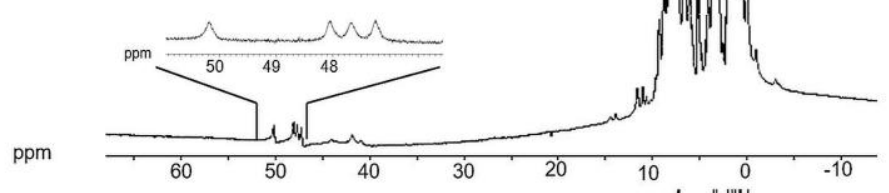

b) $\mathrm{Fe}^{\mathrm{Il}}-\mathrm{Cu}$ $\rightarrow\left[\mathrm{Fe}-\mathrm{O}_{2}-\mathrm{Cu}\right]^{+}$

$S=0$ hexacoordinated low spin

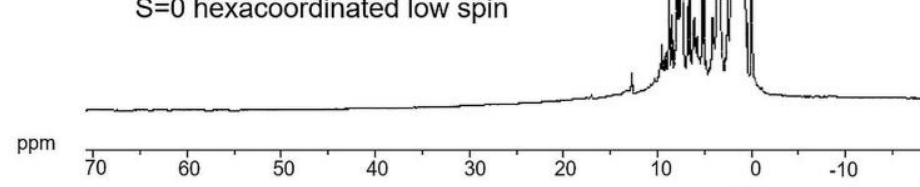

c) $\left[\mathrm{Fe}-\mathrm{O}_{2}-\mathrm{Cu}\right]^{+} \longrightarrow \mathrm{Fe}^{\mathrm{II}}-\mathrm{CO}-\mathrm{Cu}^{\mathrm{l}}$
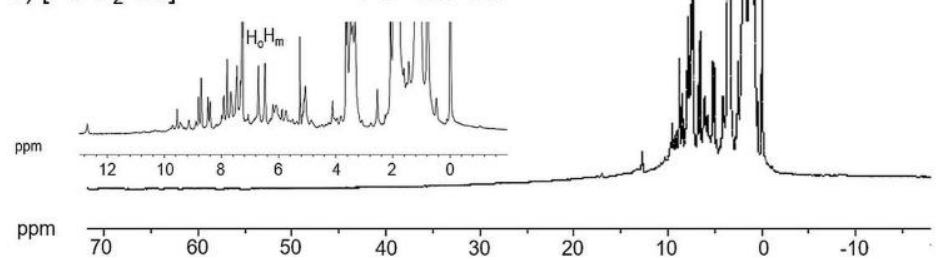

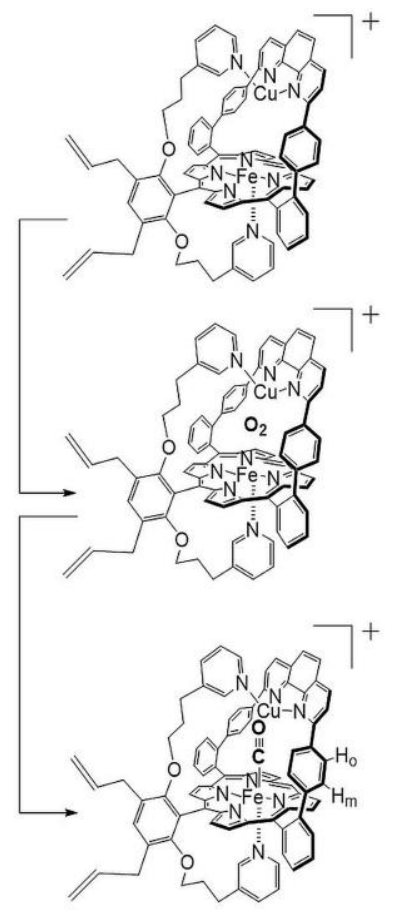

Figure 3. ${ }^{1} \mathrm{H}$ NMR spectral evolution of $\left[1 \mathbf{F e}^{\mathrm{II}} \mathrm{Cu}^{\mathrm{I}}\right]$ during the reduction of $\mathrm{Fe}^{\mathrm{III}}$ to $\mathrm{Fe}^{\mathrm{II}}$ and successive oxygen and carbon monoxide bindings ( $300 \mathrm{MHz}, \mathrm{CDCl}_{3}, 298 \mathrm{~K}$ ).

Upon exposure to oxygen, the $\left[\mathbf{1} \mathbf{F e}^{\mathrm{II}} \mathbf{C u}^{\mathrm{I}}\right]^{+}$complex instantly lost its paramagnetic features to yield a diamagnetic spectrum; however, the spectrum was too complex to be interpreted (Figure 3). Although the diamagnetic character of the species may result from a strong antiferromagnetic coupling of $\mathrm{Fe}^{\mathrm{III}}$ and $\mathrm{Cu}^{\mathrm{II}}$ through a $\mu$-peroxo bridge, the disappearance of the downfield $\beta$ pyrrolic protons is also highly characteristic of the formation of an oxygenated heme model and was previously assigned to the formation of a $\left[\mathrm{Fe}^{\mathrm{III}} \mathrm{O}_{2}{ }^{-}\right]$species [20]. Several data indicated the probable formation of such an intermediate. First, the reversibility of the oxygen binding in the heme model was verified by exposure to a $\mathrm{CO}$ atmosphere that generated a new diamagnetic $\left[1 \mathrm{Fe}^{\mathrm{II}}-\mathrm{CO}-\mathrm{Cu}^{\mathrm{I}}\right]^{+}$species. Second, when a $\left[1 \mathrm{Fe}^{\mathrm{II}}\right]$ species was generated in the presence of $N$ - 
methylimidazole, which binds within the strap, exposure to oxygen provided an oxygenated species within minutes (see supporting information).

The ${ }^{1} \mathrm{H}$ NMR spectrum of $\left[\mathbf{2} \mathbf{F e}^{\mathrm{III}} \mathbf{C u}^{\mathrm{I}}\right]^{2+}$ was similar to that of its $\left[\mathbf{2} \mathrm{Fe}^{\mathrm{III}}\right]^{+}$precursor. Upon reduction, the spectrum of $\left[2 \mathrm{Fe}^{\mathrm{II}} \mathbf{C u}^{\mathrm{I}}\right]^{+}$was relatively well resolved, indicating a diamagnetic, hexacoordinated species that contrasts with the paramagnetic species observed for $\left[\mathbf{1 F e} e^{\mathrm{II}} \mathbf{C u}^{\mathrm{I}}\right]^{+}$. Little change was observed after bubbling $\mathrm{O}_{2}$ into the solution. These observations suggested that reduction of $\left[2 \mathbf{F e}^{\mathrm{III}} \mathbf{C u}^{\mathrm{I}}\right]^{2+}$ to its iron(II) analogue generated a partially oxygenated species, probably due to the presence of trace amounts of oxygen during the reduction and a high affinity of the iron(II)-copper(I) complex for oxygen. The reversible binding of oxygen was demonstrated by the subtle changes in the ${ }^{1} \mathrm{H}$ NMR spectrum in the presence of $\mathrm{CO}$ (see supporting information).

Raman spectroscopy provided further confirmation of the high affinity of $\left[2 \mathbf{F e}^{\mathrm{II}} \mathbf{C u}^{\mathrm{I}}\right]^{+}$for oxygen (Figure 4). The Raman spectrum of $\left[2 \mathbf{F e}^{\mathrm{III}} \mathbf{C} \mathbf{u}^{\mathrm{I}}\right]^{2+}$ (spectrum A) exhibited structuresensitive bands at $1362\left(v_{4}\right.$ mode $)$ and $1551 \mathrm{~cm}^{-1}\left(v_{2}\right.$ mode $)$, which are expected for a high spin Fe $\mathrm{III}^{\mathrm{III}}$ complex [21]. Upon reduction of the complex (spectrum B), two sets of signals could be seen: the main signals at 1343 and $1539 \mathrm{~cm}^{-1}$ and the shoulders at 1362 and $1558 \mathrm{~cm}^{-1}$. The main signals are characteristic of high spin $\mathrm{Fe}^{\mathrm{II}}$ species and the shoulders of low spin hexacoordinated $\mathrm{Fe}^{\mathrm{II}}$ species. Upon exposure to $\mathrm{O}_{2}$ (spectrum C), the signals at 1362 and $1558 \mathrm{~cm}^{-1}$ increased in intensity. Dithionite reduction of the $\left[2 \mathrm{Fe}^{\mathrm{III}} \mathbf{C u}^{\mathrm{I}}\right]^{2+}$ complex generated partially oxygenated $\left[2 \mathrm{Fe}^{\mathrm{II}} \mathrm{Cu}^{\mathrm{I}}\right]^{+}$species, again confirming the high affinity of the complex for oxygen and its ability to bind traces of oxygen present in common grade commercial inert gases. The Raman data did not show the contribution of the $\mathrm{Fe}-\mathrm{O}, \mathrm{Cu}-\mathrm{O}$ or the $\mathrm{OO}$ vibrational modes; thus, precise coordination form of the oxygen molecule could not be determined. Although the $\left[\mathbf{1} \mathbf{F e}^{\mathrm{II}} \mathbf{C} \mathbf{u}^{\mathrm{I}}\right]^{+}$ was also studied by Raman spectroscopy, the ill-resolved signals could not be interpreted. 


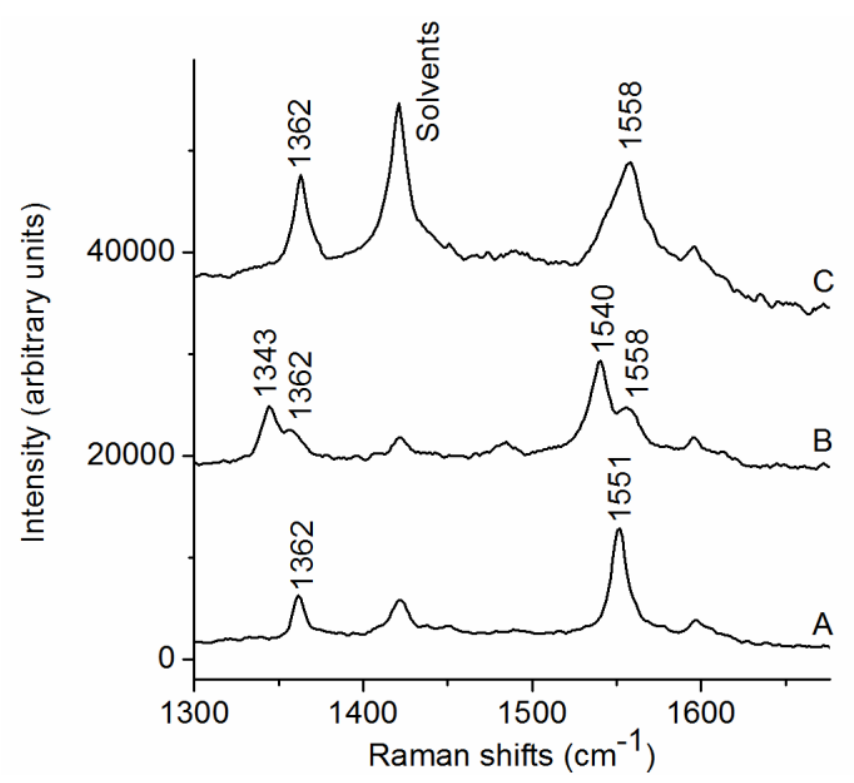

Figure 4. Raman spectra at $457 \mathrm{~nm}$ of: (A) the complex $\left[2 \mathbf{F e}^{\mathrm{III}} \mathbf{C u}^{\mathrm{I}}\right]^{2+}$, (B) $\left[2 \mathrm{Fe}^{\mathrm{III}} \mathbf{C u}^{\mathrm{I}}\right]^{2+}$ after dithionite reduction and (C) $\left[2 \mathrm{Fe}^{\mathrm{III}} \mathrm{Cu}^{\mathrm{I}}\right]^{2+}$ after dithionite reduction and exposure to $\mathrm{O}_{2}$.

\section{Electrochemical studies of the iron-copper complexes}

The redox properties of the iron and iron-copper complexes of $\mathbf{2}$ were investigated, both in solution and adsorbed onto a rotating ring disk electrode (RRDE). The redox behavior of $\mathbf{1}$ was previously reported [16] but will be discussed in comparison to the metal complexes of $\mathbf{2}$. The $\left[1 \mathrm{Fe}^{\mathrm{III} / \mathrm{II}}\right]^{+/ 0}$ redox couple exhibits a slightly broadened reoxidation peak, $\left(-0.63 \mathrm{~V} / \mathrm{Fc} \mathrm{c}^{+} / \mathrm{Fc}, \mathrm{I}_{\mathrm{Pa}} / \mathrm{I}_{\mathrm{Pc}}=\right.$ 0.65 ) which is consistent with the coordination of the distal pyridine that probably competes with the distal binding of residual water, residual oxygen or a chloride anion present in solution. The $\left[2 \mathrm{Fe}^{\mathrm{III} / \mathrm{II}}\right]^{+/ 0}$ redox couple exhibits a strikingly different behavior with an ill-defined reoxidation peak $\left(\mathrm{E}_{\mathrm{pa} 2}=-0.67 \mathrm{~V} / \mathrm{Fc}^{+} / \mathrm{Fc}, \mathrm{E}_{\mathrm{pa} 2}=-0.48 \mathrm{~V} / \mathrm{Fc}^{+} / \mathrm{Fc}\right)$ that illustrates the five coordinate behavior of these complexes and the presence of an empty distal pocket. (Figure 5) in which slow, partial coordination/decoordination of the distal ligand and possibly subsequent coordination of residual water or a chloride occurs $[15,22]$. The coordination of the distal pyridine in $\left[\mathbf{1 F e} \mathbf{e}^{\mathrm{II}}\right]$ can be 
prevented by the insertion of copper(I) in the phenanthroline and the subsequent vacancy of the distal pocket can be confirmed by the broadening of the reoxidation peak of [1Fe $\left.{ }^{\mathrm{II}}\right]$. Although not necessary in the case of $\left[\mathbf{2} \mathbf{F e}^{\mathrm{II}}\right]$, the incorporation of copper was clearly established after the addition of one equivalent of $\left[\mathrm{Cu}\left(\mathrm{CH}_{3} \mathrm{CN}\right)_{4} \mathrm{PF}_{6}\right]$ dissolved in acetonitrile. Thus, the shapes of the return peak in the $\mathrm{Fe}{ }^{\mathrm{III} / \mathrm{II}}$ couple of $\left[\mathbf{2} \mathbf{F e}^{\mathrm{III}} \mathbf{C u}^{\mathrm{I}}\right]^{2+}$ (Figure 5) and $\left[\mathbf{1 F e} \mathbf{e}^{\mathrm{III}} \mathbf{C u}^{\mathrm{I}}\right]^{2+}[16]$ confirmed that the $\mathrm{Fe}^{\mathrm{II}}$ core remained pentacoordinated after reduction. In the case of $\left[2 \mathbf{F e}^{\mathrm{III}} \mathbf{C u}^{\mathrm{I}}\right]^{2+}$, despite degassing the solution by argon bubbling, a notable enhancement of the cathodic current and a reduction of $\mathrm{Fe}^{\mathrm{III}}$ at a less reductive potential are observed (Figure 5a). Again, this behavior is explained by the extremely high affinity of $\left[2 \mathbf{F e}^{\mathrm{II}} \mathbf{C} \mathbf{u}^{\mathrm{I}}\right]^{+}$for oxygen and the subsequent reduction of oxygen traces present in the solution. This observation explains the difficulties encountered in characterizing the deoxygenated Fe ${ }^{\mathrm{II}}$ species by EPR, UV and NMR spectroscopies under our conditions. Upon intentional exposure of $\left[2 \mathbf{F e}^{\mathrm{III}} \mathbf{C u}^{\mathrm{I}}\right]^{2+}$ to oxygen, the voltammogram displays a similar enhancement of the cathodic current, suggesting a catalytic process and an only slightly facilitated $\mathrm{Fe}^{\mathrm{III}}$ reduction process (Figure 5a, $\mathrm{E}_{\mathrm{pc} 1}=-0.54 \mathrm{~V}, \mathrm{E}_{\mathrm{pc} 2}=-0.66 \mathrm{~V}$ ). In addition, the deliberate exposure to oxygen also affects the $\mathrm{Cu}^{\mathrm{II} / \mathrm{I}}$ redox couple (without $\mathrm{O}_{2}:+0.31 \mathrm{~V} / \mathrm{Fc}^{+} / \mathrm{Fc}$, $\mathrm{I}_{\mathrm{Pa}} / \mathrm{I}_{\mathrm{Pc}}=1$; with $\left.\mathrm{O}_{2}:+0.19 \mathrm{~V} / \mathrm{Fc}^{+} / \mathrm{Fc}, \mathrm{I}_{\mathrm{Pa}} / \mathrm{I}_{\mathrm{Pc}}=0.3\right)$ in $\left[2 \mathrm{Fe}^{\mathrm{III}} \mathbf{C u}^{\mathrm{II}}\right]^{3+}$. This effect can be tentatively explained by the presence of exogenic ligands $\left(\mathrm{Cl}^{-}\right.$or $\mathrm{H}_{2} \mathrm{O}, \mathrm{HO}^{-}$or $\left.\mathrm{HOO}^{-}\right)$in the distal cavity. 
(a)

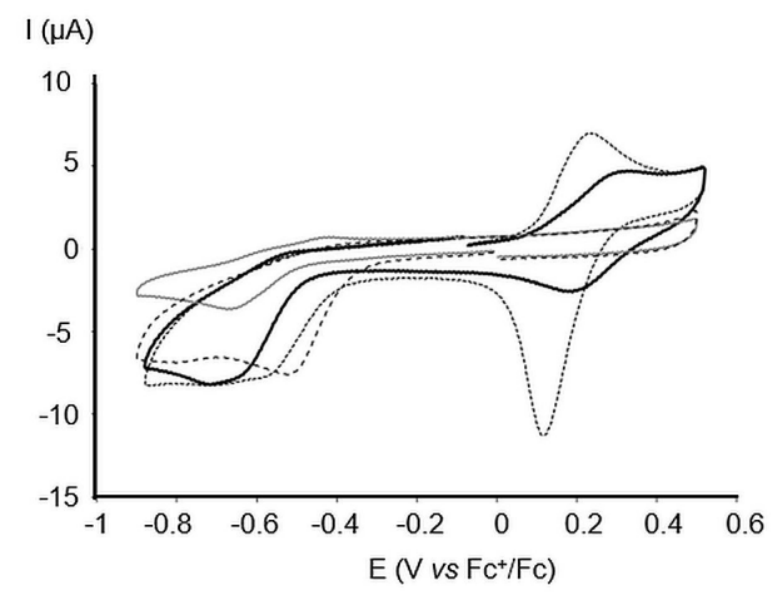

I $(\mu \mathrm{A})$

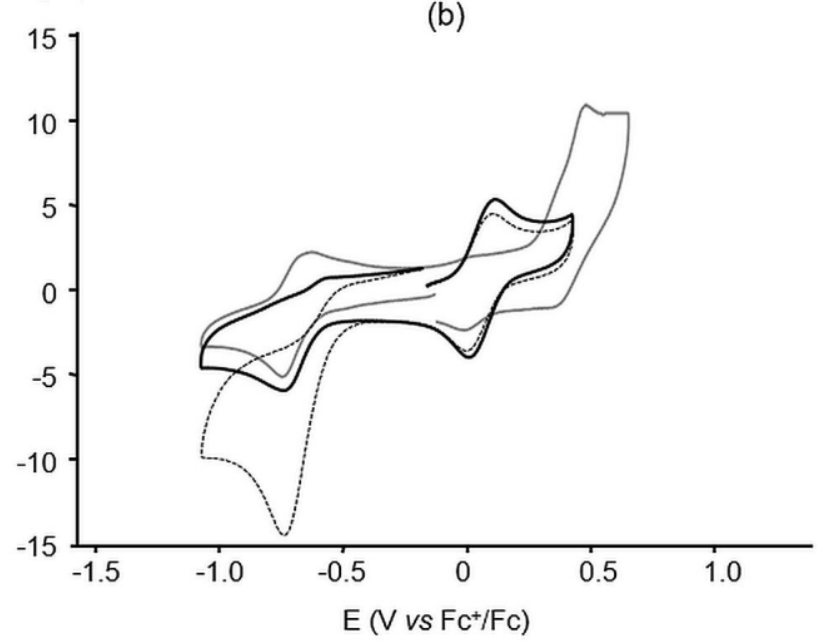

Figure 5. Cyclic voltammograms of complexes of (a) 2 and (b) 1 in $\mathrm{CH}_{2} \mathrm{Cl}_{2}+\mathrm{TBAPF}_{6}$. Gray traces: $\mathrm{Fe}^{\mathrm{III}}$ complexes; --

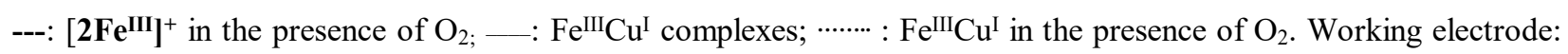
glassy carbon, counter electrode: $\mathrm{Pt}$ wire, pseudo reference $\mathrm{Pt}$ wire with $\mathrm{Fc}^{+} / \mathrm{Fc}$ used as an internal standard, $\mathrm{V}=0.1$ V/s.

As reported earlier [16], in the presence of $\mathrm{O}_{2},\left[\mathbf{1 F e}^{\mathrm{III}} \mathbf{C u}^{\mathrm{I}}\right]^{2+}$ displayed a catalytic behavior as soon as the $\mathrm{Fe}^{\mathrm{III} / \mathrm{II}}$ potential was reached, as shown by the significant increase of the cathodic current (see Figure 5b) whereas in a degassed solution only the reduction of $\mathrm{Fe}^{\mathrm{III}}$ is observed. The redox potentials of the reduction of iron(III) as well as the oxidation of copper(I) of [1Fe $\left.\mathbf{I I I}^{\mathrm{III}} \mathbf{C u}^{\mathrm{I}}\right]^{2+}$ were unaffected by the presence of oxygen $\left(\mathrm{E}_{\mathrm{pc}}=-0.62 \mathrm{~V} / \mathrm{Fc}^{+} / \mathrm{Fc} ; \mathrm{E}_{\mathrm{Cu}(\mathrm{II}) / \mathrm{Cu}(\mathrm{I})}=0.12 \mathrm{~V} / \mathrm{Fc}^{+} / \mathrm{Fc}\right.$, $\left.I_{p a} / I_{p c}=1\right)$. These observations suggest that the behavior of each model is drastically affected by the difference in the rigidity or flexibility of their respective organic framework. Whereas concerted motions of the two pendant pyridyl side arms allow a better controlled electrochemical reactivity of $\left[\mathbf{1 F e}^{\mathrm{III}} \mathbf{C u}^{\mathrm{I}}\right]^{2+}$ in the presence of oxygen, the sterically controlled coordination induced by the use of fully independent picolinyl side arms yields a much higher reactivity. Another significant difference is the essential role played by the copper to ensure a vacant distal site in the case of structure $\mathbf{1}$, whereas with $\mathbf{2}$, a higher affinity for oxygen is inherent to the 
sterically encumbered structure and the insertion of copper is not a prerequisite to the binding of oxygen, or other distal exogenic ligands. Cyclic voltammetry does not provide information regarding the dielectronic or tetraelectronic nature of the oxygen reduction; hence, rotating ring disk electrode experiments were performed to gain deeper insight into the reactivity of each structure.

\section{Electrocatalytic RRDE studies}

For models $\left[\mathbf{1 F e} e^{I I}\right]$ and $\left[\mathbf{1 F e} \mathbf{I I}^{\mathrm{II}}-\mathbf{C u}^{\mathrm{I}}\right]^{+}$, it was previously reported that the presence of copper(I) in the latter facilitated the reduction of oxygen [16]. In addition, hydrogen peroxide production was lower in the presence of copper than in the model containing just iron(II). However, for models $\left[2 \mathbf{F e}^{\mathbf{I I}}\right]$ and $\left[2 \mathbf{F e}^{\mathrm{II}}-\mathbf{C u}^{\mathbf{I}}\right]^{+}$, the rotating ring-disk electrode (RRDE) studies [10,23] described below showed that both models were less efficient than $\left[\mathbf{1 F e} e^{\mathrm{III}}\right]^{+}$and $\left[\mathbf{1 F} e^{\mathrm{III}} \mathbf{C u}^{\mathrm{I}}\right]^{\mathbf{2 +}}$ in the electrocatalytic reduction of $\mathrm{O}_{2}$.

The catalyst precursors $\left[2 \mathbf{F e}^{\mathrm{III}}\right]^{+}$and $\left[\mathbf{2} \mathbf{F e}^{\mathrm{III}} \mathbf{C u}^{\mathrm{I}}\right]^{2+}$ were adsorbed by drop-casting a $1 \mathrm{mM}$ solution in $\mathrm{CH}_{2} \mathrm{Cl}_{2}$ onto the edge oriented pyrrolitic graphite (EOPG) disk of the RRDE to prevent contamination of the platinum disk devoted to hydrogen peroxide oxidation. The RRDE was then immersed in an aqueous phosphate buffer saturated with oxygen $(\mathrm{pH}=7)$. The noncatalyzed reduction of oxygen on bare EOPG was recorded as a reference. Figure 6 summarizes the evolution of the reduction catalytic current/voltage curves for the edge-oriented pyrolitic graphite (EOPG) disk (bottom graph) and the concomitant detection of hydrogen peroxide at the platinum ring for which the potential was set at $0.8 \mathrm{~V}$ (vs. $\mathrm{AgCl} / \mathrm{Ag}$ ) (top graph). With both $\left[2 \mathbf{F e}^{\mathrm{II}}\right]$ and $\left[\mathbf{2} \mathbf{F e}^{\mathrm{II}} \mathbf{C u}^{\mathrm{I}}\right]^{+}, \mathrm{O}_{2}$ was reduced at nearly the same potential as in the noncatalyzed reduction. Production of $\mathrm{H}_{2} \mathrm{O}_{2}$ was low with $\left[\mathbf{2 F e} e^{\mathrm{II}}\right]$ and even lower with $\left[\mathbf{2} \mathbf{F e}^{\mathrm{II}} \mathbf{C u}^{\mathrm{I}}\right]^{+}$(top graph in Figure 6), but allowed us to estimate the contribution of the two-electron reduction of oxygen. 
In the presence of $\left[2 \mathrm{Fe}^{\mathrm{III}}\right]^{+}, 30 \%$ of the reduction of $\mathrm{O}_{2}$ occurred via a two-electron mechanism and $70 \%$ by a four-electron mechanism. The contribution of the latter mechanism increased to $75 \%$ in the presence of $\left[2 \mathbf{F e}^{\mathrm{II}} \mathbf{C} \mathbf{u}^{\mathrm{I}}\right]^{+}$.

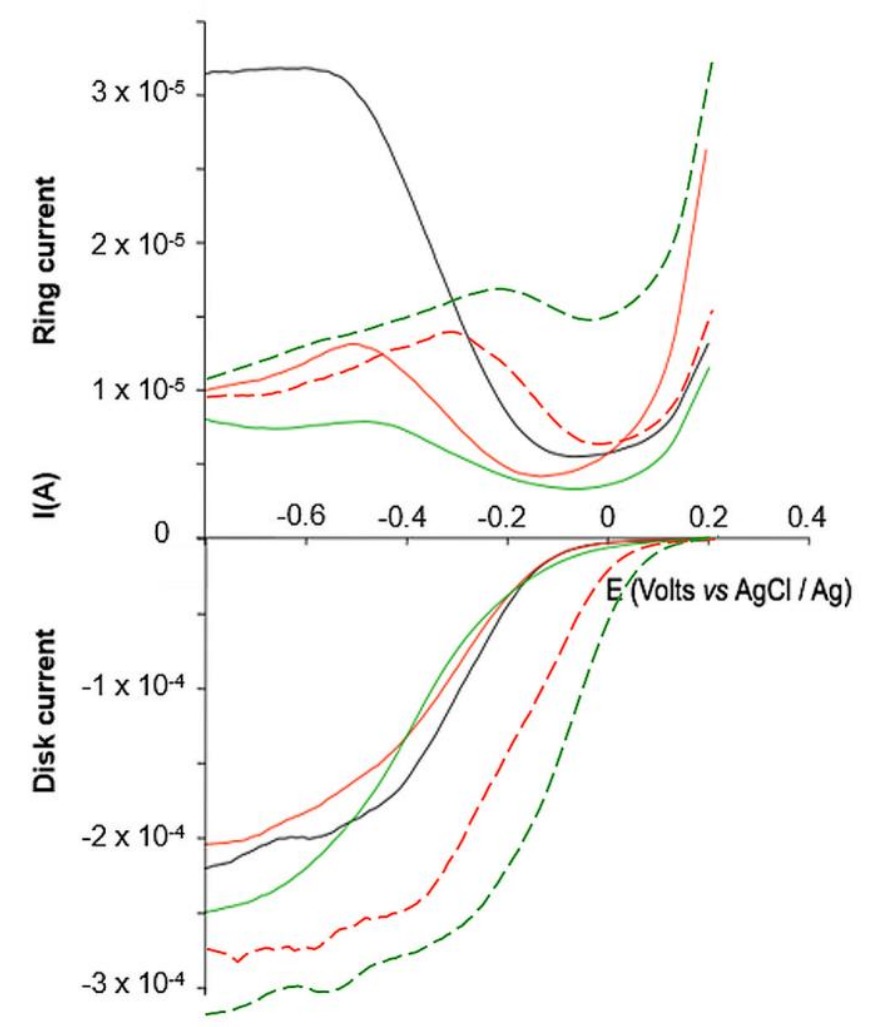

Figure 6. RRDE electrocatalytic studies of $\mathrm{O}_{2}$ reduction on pure edge-oriented pyrolitic graphite (black) and in the presence of $\left[\mathbf{2} \mathbf{F e}^{\mathrm{II}}\right]$ (solid red), $\left[\mathbf{2} \mathrm{Fe}^{\mathrm{II}}-\mathbf{C u}^{\mathrm{I}}\right]^{+}$(solid green), compared with $\left[\mathbf{1} \mathrm{Fe}^{\mathrm{II}}\right]$ (dashed red) and $\left[\mathbf{1} \mathrm{Fe}^{\mathrm{II}}-\mathbf{C u}^{\mathrm{I}}\right]^{+}$ (dashed green) deposited on the graphite disk.

Comparison of the respective behavior of complexes of $\mathbf{1}$ and $\mathbf{2}$ in terms of tetra-electronic efficiency shows that $\left[2 \mathrm{Fe}^{\mathrm{II}}-\mathrm{Cu}^{\mathrm{I}}\right]^{+}$(solid green line in Figure 6) is the most efficient with the least $\mathrm{H}_{2} \mathrm{O}_{2}$ produced at the EOPG electrode and detected at the ring electrode, confirming the previous observation of the higher four-electron efficiency of our models in the presence of $\mathrm{Cu}^{\mathrm{I}}$. Comparison of the reduction potentials for oxygen of $\left[1 \mathbf{F e}^{\mathrm{II}} \mathbf{C u}^{\mathrm{I}}\right]^{+}$and $\left[2 \mathrm{Fe}^{\mathrm{II}} \mathrm{Cu}^{\mathrm{I}}\right]^{+}$shows that the more electron donating picolinyl side arms is detrimental to the efficiency of both $\left[2 \mathrm{Fe}^{\mathrm{II}}\right]^{2+}$ (solid 
red) and $\left[2 \mathrm{Fe}^{\mathrm{II}}-\mathrm{Cu}^{\mathrm{I}}\right]^{+}$as the dominant four-electron reduction occurs with no gain in potential, which is not the case when pyridinyl auxiliary ligands are use in $\left[\mathbf{1 F} e^{\mathrm{II}}\right]$ and $\left[\mathbf{1 F e}^{\mathrm{II}} \mathbf{C u}^{\mathrm{I}}\right]^{+}$.

\section{CO binding}

Structural changes in the environment of metalloproteins also affect the binding of carbon monoxide. In heme proteins, as well as their superstructured iron porphyrin models, the CO stretching band frequencies and the bandwidth highly depend on the nature of the environment of the binding pocket [24]. The reactivity of the iron and iron-copper complexes of $\mathbf{2}$ towards CO was thus examined by ATR-FTIR at room temperature and compared to previous studies [16]

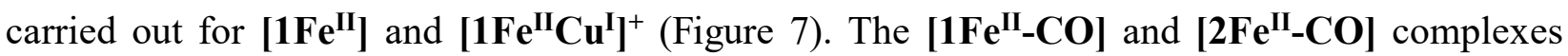
(black plots) exhibited very similar CO stretching frequencies (1981 and $1980 \mathrm{~cm}^{-1}$ respectively). These values are typical for stretching frequencies of $\mathrm{CO}$ coordinated to $\mathrm{Fe}^{\mathrm{II}}$ porphyrins possessing a proximal axial base [16].

In contrast, the binding of $\mathrm{CO}$ was very different for the two bimetallic complexes (gray plots). Whereas [1 $\left.\mathbf{F e}^{\mathrm{II}} \mathbf{C u}^{\mathrm{I}}-\mathbf{C O}\right]^{+}$exhibited two $\mathrm{CO}$ stretching bands at 1977 and $1947 \mathrm{~cm}^{-1}$, only one broad band centered at $1972 \mathrm{~cm}^{-1}$ was observed for $\left[2 \mathbf{F e}^{\mathrm{II}} \mathbf{C u}^{\mathrm{I}}-\mathbf{C O}\right]^{+}$. The absence of other stretching bands at higher frequency for both complexes indicates that $\mathrm{CO}$ is bound to the iron rather than to the copper center [25]. It thus appears that changing the position of the two pyridine ligands drastically alters the coordination of $\mathrm{CO}$ in the two bimetallic complexes. It is likely that the tension created within the pyridyl arms, which are on the same phenyl ring in $\left[1 \mathrm{Fe}^{\mathrm{II}} \mathrm{Cu}^{\mathrm{I}}\right]^{+}$, induces a net tilt of the phenanthroline strap upon copper coordination. The CO ligand is then blocked in two different orientations on the distal side of the porphyrin. In one of the two orientations, $\mathrm{CO}$ interacts strongly with the charged copper center, causing a significant downshift of its stretching frequency to $1947 \mathrm{~cm}^{-1}$. In the more flexible $\left[2 \mathbf{F e}^{\mathrm{II}} \mathbf{C u}^{\mathrm{I}}\right]^{+}$complex, the 
proximal and distal pyridines can move independently of one other. There is thus less restriction to the movement of the bound $\mathrm{CO}$.

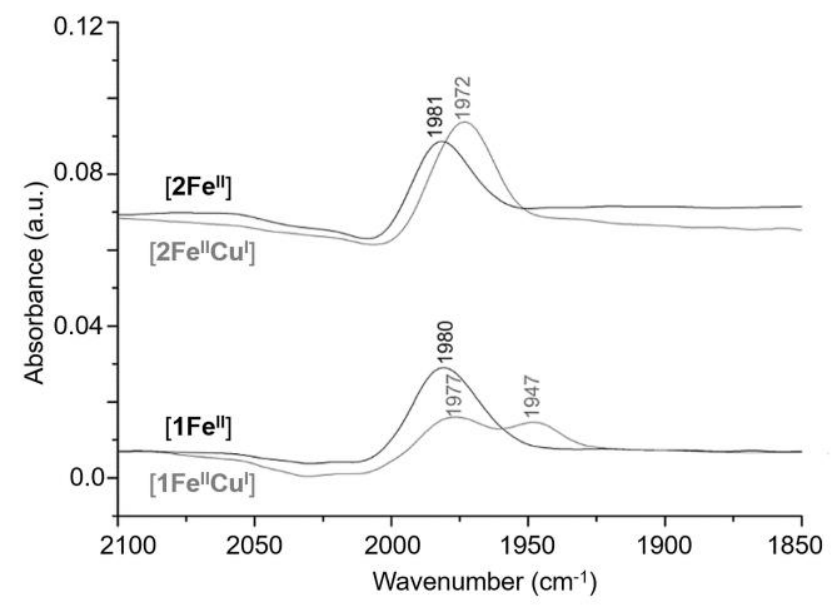

Figure 7: ATR-FTIR CO stretching bands of the $\left[\mathbf{1 F e} \mathbf{I I}^{\mathrm{II}}-\mathbf{C O}\right]$ and $\left[\mathbf{1 F e} \mathbf{e}^{\mathrm{II}}-\mathbf{C O}-\mathbf{C} \mathbf{u}^{\mathrm{I}}\right]^{+}$complexes (bottom) and the $\left[2 \mathrm{Fe}^{\mathrm{II}}-\mathrm{CO}\right]$ and $\left[2 \mathrm{Fe}^{\mathrm{II}}-\mathrm{CO}-\mathrm{Cu}^{\mathrm{I}}\right]^{+}$complexes (top).

\section{Conclusion}

Comparative studies of $\mathbf{1}$ and $\mathbf{2}$, which differ by only small changes in their distal binding site, highlight how architectural constraints as well as the nature of the built-in proximal and distal ligands influence the affinity of cytochrome c oxidase models for oxygen and their subsequent ability to electrocatalytically reduce oxygen to water. The higher affinity of [2Fe $\left.{ }^{\mathrm{II}}\right]$ than $\left[\mathbf{1 F e} \mathbf{E}^{\mathrm{II}}\right.$ ] for oxygen arises from the use of a bulky picoline as auxiliary ligand that is unable to enter the phenanthroline pocket, thus ensuring an accessible distal binding site in $\left[\mathbf{2 F} \mathbf{e}^{\mathrm{II}}\right]$. The bimetallic iron-copper complexes showed the same trend in oxygen affinity as their iron precursors. Moreover, both bimetallic complexes reversibly coordinate $\mathrm{O}_{2}$, making their oxygenated complexes acceptable mimics of the first intermediate in the catalytic cycle of cytochrome c oxidase. Despite the ease with which $\left[2 \mathbf{F e}^{\mathrm{II}} \mathbf{C} \mathbf{u}^{\mathrm{I}}\right]^{+}$binds oxygen, this complex less efficiently 
catalyzed the four-electron reduction of $\mathrm{O}_{2}$ than $\left[\mathbf{1 F e}^{\mathrm{II}} \mathbf{C u}^{\mathrm{I}}\right]^{+}$in terms of overpotential, but was more efficient regarding the undesired production of reactive oxygen species These results demonstrate how very small changes in the structure of cytochrome c oxidase functional models drastically modify their behavior in the presence of both oxygen and carbon monoxide. In both ligands studied during the course of this work, the basic framework that determines the distance between the ferrous iron and the cuprous center is maintained. The only differences in the series of models are the basicity of the axial base and the overall flexibility of the pendant side arms. The main conclusion of this work is that rationalizing the behavior of hemoprotein models in drastically different families of ligands is a very difficult task. Further structural refinements are in progress to specifically address the influence of each parameter and optimize the electrocatalytic properties of these models.

Acknowledgements The CNRS, the Ministère de l'Education Nationale de la Recherche et de la Technologie and the French EPR Federation of Research (REseau NAtional de Rpe interDisciplinaire, RENARD, Fédération IR RPE CNRS 3443) are gratefully acknowledged for financial support. This work was supported by the CHEMBLAST (Conception of HEmoprotein Models for Biomimetic Large scale Applications and mechanistic STudies) program of the National Research Agency (Grant \# 06-BLAN-0230).

Supporting Information. Synthesis of metal complexes, UV-visible spectroscopic titrations of the iron(III) complexes with imidazoles and with $\mathrm{Cu}(\mathrm{I})$, EPR and ${ }^{1} \mathrm{H}$ NMR spectra. 


\section{REFERENCES}

${ }^{1}$ For a recent review of the reaction mechanism, see: S. Yoshikawa, A. Shimada, Chem. Rev. 115 (2015) $1936-1989$.

2 S. Iwata, C. Ostermeier, B. Ludwig, H. Michel, Nature 376 (1995) 660-669.

${ }^{3}$ S. Yoshikawa, K. Shinzawa-Itoh, R. Nakashima, R. Yaono, E. Yamashita, N. Inoue, M. Yao, M. J. Fei, C. P. Libeu, T. Misushima, H. Yamaguchi, T. Tomizaki, T. Tsukihara, Science, 280 (1998) 1723-1729.

4 a) E. Kim, E. E. Chufán, K. Kamaraj, K. D. Karlin, Chem. Rev. 104 (2004) 1077-1134; b) J. P. Collman, R. Boulatov, C. J. Sunderland, L. Fu, Chem. Rev. 104 (2004) 561-588.

5 a) J. P. Collman, R. A. Decréau, J. Yoon, E. I. Solomon, J. Am. Chem. Soc. 129 (2007) 5794; b) R. A. Decréau, J. P. Collman, A. Hosseini, Chem. Soc. Rev. 39 (2010) 1291-1301.

${ }^{6}$ E. E. Chufán, S. C. Puiu, K. D. Karlin, Acc. Chem. Res. 40 (2007) 563-572.

7 a) D. Ricard, B. Andrioletti, M. L'Her, B. Boitrel, Chem. Commun. (1999) 1523; b) D. Ricard, A. Didier, M. L'Her, B. Boitrel, C. R. Chimie, 5 (2002), 33; c) C. Ruzié, P. Even-Hernandez, B. Boitrel, Org. Lett. 10 (2008) 26732676.

8 Z. Halime, H. Kotani, Y. Li, S. Fukuzumi, K. D. Karlin, Proc. Natl. Acad. Sci. 108 (2011) 13990-13994.

${ }^{9}$ For selected examples, see: a) J. P. Collman, P. C. Fu, B. Boitrel, X. Zhang, T. A. Eberspacher, L. Fu, J. Am. Chem. Soc. 116 (1994) 978; b) J. P. Collman, Inorg. Chem. 36 (1997) 5145-5155; c) A. Didier, M. L'Her, B. Boitrel, Org.

Biomol. Chem. 1 (2003) 1274; d) G. Charalambidis, K. Ladomenou, B. Boitrel, A. G. Coutsolelos, Eur. J. Org. Chem. 8 (2009) 1263;

10 a) J. P. Collman, L. Fu, P. C. Herrmann, Science, 275 (1997) 949; b) J. P. Collman, S. Ghosh, Inorg. Chem. 49 (2010) 5798-5810.

${ }^{11}$ S. M. Adam, I. Garcia-Bosch, A. W. Schaefer, S. K. Sharma, M. A. Siegler, E. I. Solomon, K. D. Karlin, J. Am. Chem. Soc. 139 (2017) 472-481.

12 J. A. Wytko, E. Graf, J. Weiss, J. Org. Chem. 57 (1992) 1015-1018.

${ }^{13}$ C. Kahlfuss, J. A. Wytko, J. Weiss, ChemPlusChem (2017) DOI: 10.1002/cplu.201600557.

${ }^{14}$ F. Melin, C. Boudon, M. Lo, K. J. Schenk, M. Bonin, P. Ochsenbein, M. Gross, J. Weiss, J. Porph. Phthalocyanines 11 (2007) 212-221.

${ }^{15}$ M. Lo, D. Mahajan, J. A. Wytko, C. Boudon, J. Weiss, Org. Lett. 11 (2009) 2487-2490.

${ }^{16}$ F. Melin, A. Trivella, M. Lo, C. Ruzié, N. Oueslati, J. A. Wytko, B. Boitrel, C. Boudon, P. Hellwig, J. Weiss, J. Inorg. Biochem. 108 (2012) 196-202.

${ }^{17}$ P. Vorburger, J. A. Wytko, J. Weiss, J. Porphyrins Phthalocyanines 18 (2014) 804-813.

18 P. Weyermann, F. Diederich, Helv. Chim. Acta, 85 (2002) 599-617.

${ }^{19}$ F. A. Walker, Chem. Rev. 104 (2004) 589-615.

20 J. P. Collman, C. J. Sunderland, K. E. Berg, M. A. Vance, A. I. Solomon, J. Am. Chem. Soc. 125 (2003) $6648-$ 6649.

21 a) T. G Spiro, T. C. Strekas, J. Am. Chem. Soc. 96 (1974) 338-345; b) P. Stein, J. M. Burke, T. G. Spiro, J. Am. Chem. Soc. 97 (1975) 2304-2305; c) T. G. Spiro, J. M. Burke, J. Am. Chem. Soc. 98 (1976) 5482-5489; d) J. M. Burke, J. R. Kincaid, S. Peters, R. R. Gagne, J. P. Collman, T. G. Spiro, J. Am. Chem. Soc. 100 (1978) $6083-6088$.

${ }^{22}$ L. A. Bottomley, K. M. Kadish, Inorg. Chem. 20 (1981) 1348-1357.

${ }^{23}$ RRDE studies have been employed to study the electrocatalytic reduction of oxygen in other cytochrome c oxidase models. See: a) J. P. Collman, S. Ghosh, A. Dey, R. A. Decréau, Y. Yang, J. Am. Chem. Soc. 131 (2009) 50345035 .

24 See for instance for a review: P. Hellwig, F. Melin, In Recent Applications of Infrared Spectroscopy and Microscopy in Chemistry, Biology and Medicine. Handbook of Porphyrin Science; K. M. Kadish, K. M. Smith, R. Guilard, Eds. World Scientific, Singapore, 2010; Vol. 7, pp 437-493.

25 J. P. Collman, C. J. Sunderland, R. Boulatov, Inorg. Chem. 41 (2002) 2282-2291. 